\title{
Protection against Toxoplasma gondii cysts in pigs immunized with rROP2 plus Iscomatrix
}

\author{
Proteção contra cistos de Toxoplasma gondii em suínos imunizados com \\ rROP2 associado à Iscomatrix
}

\begin{abstract}
Ivo Alexandre Leme da Cunha' (1); Dauton Luiz Zulpo² (D); Alexandra Taroda ${ }^{\mathbb{D}}$; Luiz Daniel de Barros ${ }^{3}$ (D);

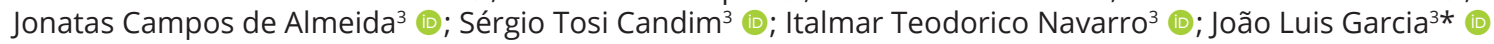

'Laboratório de Parasitologia Aplicada, Centro de Ciências Agrárias e Ambientais, Universidade Federal do Maranhão - UFMA, Chapadinha, MA, Brasil

${ }^{2}$ Faculdade de Medicina Veterinária, Pontifícia Universidade Católica do Paraná - PUCPR, Toledo, PR, Brasil ${ }^{3}$ Laboratório de Protozoologia Animal, Departamento de Medicina Veterinária Preventiva, Universidade Estadual de Londrina - UEL, Londrina, PR, Brasil
\end{abstract}

How to cite: Cunha IAL, Zulpo DL, Taroda A, Barros LD, Almeida JC, Candim ST, et al. Protection against Toxoplasma gondii cysts in pigs immunized with rROP2 plus Iscomatrix. Braz J Vet Parasitol/Rev Bras Parasitol Vet 2020; 29(4): e012620. https://doi. org/10.1590/S1984-29612020077

\begin{abstract}
This study aimed to evaluate the humoral immune response in pigs immunized intranasally and intramuscularly with recombinant Toxoplasma gondii rROP2 protein in combination with the adjuvant Iscomatrix. Twelve mixed breed pigs divided into three groups $(n=4)$ were used, G1 received recombinant ROP2 proteins ( $200 \mu \mathrm{g} / \mathrm{dose})$ plus Iscomatrix, G2 received PBS plus Iscomatrix, and G3 as the control group. The intranasal (IN) and intramuscular (IM) routes were used. Animals were challenged orally with VEG strain oocysts and treated on day three after challenge. Fever, anorexia, and prostration were the clinical signs observed in all animals. All the G1 animals produced antibodies above the cut-off on the day of the challenge, while the G2 and G3 remained below the cut-off. Better partial protection against parasitemia and cyst tissue formation was observed in G1 than G3. The protection factors against tissue cyst formation were $40.0 \%$ and $6.1 \%$ for $\mathrm{G} 1$ and $\mathrm{G} 2$, respectively, compared to G3. In conclusion, there were not systemic antibody responses in pigs with IN immunization with rROP2+Iscomatrix; however, after IM immunization, those animals produced higher titers than animal controls. We associated these results with partial protection obtained against parasitemia and tissue cysts formation.
\end{abstract}

Keywords: Apicomplexa, rhoptry, organelles, vaccine, swine.

\section{Resumo}

O objetivo deste estudo foi avaliar a resposta imune humoral em suínos imunizados pelas vias intranasal e intramuscular com proteínas recombinantes rROP2 do Toxoplasma gondii associadas ao adjuvante Iscomatrix. Doze suínos cruzados divididos em 3 grupos $(n=4)$ foram utilizados. O G1 recebeu proteína recombinante ROP2 (200mg/dose) associada ao adjuvante Iscomatrix; o G2 recebeu PBS associado ao Iscomatrix; e o G3 foi o grupo controle. As vias intranasal (IN) e intramuscular (IM) foram utilizadas. Os animais foram desafiados por via oral com a cepa VEG e tratados no dia três após o desafio. Febre, anorexia e prostração foram os sinais clínicos observados em todos os animais. Todos os animais do G1 produziram anticorpos acima do ponto de corte no dia do desafio, enquanto os animais do G2 e G3 permaneceram abaixo do ponto de corte no desafio. Proteção parcial contra parasitemia e formação de cistos teciduais foram observadas nos suínos do G1 comparados ao G3. Os fatores de proteção contra a formação de cistos teciduais foram 40,0\% e 6,1\% no G1 e G2, respectivamente, comparados com o G3. Como conclusão, não houve estimulação da resposta imune humoral sistêmica nos suínos após as imunizações IN com rROP2+Iscomatrix. Estes animais, porém, após a imunização IM, produziram títulos de anticorpos mais altos que os animais controles. Esses resultados foram associados a uma proteção parcial contra a parasitemia e formação de cistos teciduais.

Palavras-chave: Toxoplasmose, roptrias, organelas, vacina, suínos. 


\section{Introduction}

Toxoplasma gondii is a protozoan parasite that can infect all warm-blooded animals, including humans (Dubey, 1994). The worst consequence of infection is abortion, which is more frequent in goats, sheep, and humans. Meat from livestock when ingested raw or undercooked is an important source of infection for humans; the risk of acquiring T. gondii infection from pork was considered higher than from other meats (Dubey, 2010). Therefore, to decrease human cases of toxoplasmosis, it is necessary to control the cyst formation in these animals; this is especially important as cysts are not detected in the official inspection service of the carcass during the slaughter line.

Previous studies have used live vaccines and killed vaccines to protect pigs against $T$. gondii cyst formation (Dubey et al., 1991, 1994; Pinckney et al., 1994; Freire et al., 2003; Kringel et al., 2004; Garcia et al., 2005; Cunha et al., 2012; Burrells et al., 2015). However, live vaccines (RH and S48) carry the risk of reverting to virulence and becoming infective for humans; therefore, it is essential to produce a killed vaccine against T. gondii (Burrells et al., 2015).

Iscomatrix is stable colloidal complexes with 40-100 nm open cage-like structures, composed of Quil-A, cholesterol, phospholipid, and an antigen, which are effective carriers of killed vaccine (Lövgren \& Morein, 1988; Copland et al., 2000). Iscomatrix induces strong Th1, Th2, and cytotoxic T lymphocyte (CTL) responses (Cox \& Coulter, 1997).

Toxoplasma gondii ROP2 is a $55 \mathrm{kDa}$ protein located in the rhoptries and found in all stages of the parasite (El Haij et al., 2006); the main function of the ROP2 is the formation of the parasitophorous vacuole with mitochondrial interactions (Nakaar et al., 2003). Additionally, ROP2 has been suggested as a candidate component for vaccines (Saavedra et al., 1996; Mishima et al., 2002; Igarashi et al., 2010).

This study aimed to immunize pigs with $T$. gondii rROP2 plus the Iscomatrix adjuvant nasally and intramuscularly and to evaluate its protection against cyst formation after challenge with a high number of oocysts.

\section{Material and Methods}

\section{Toxoplasma gondii strain}

RH and VEG T. gondii strains were used in the experiment. The RH strain was used for PCR, and antigens for the indirect fluorescent antibody test (IFAT), and the VEG strain was used for challenging the pigs. VEG strain oocysts were obtained from the feces of infected cats from a previous experimental study (Zulpo et al., 2018). Ninety days before challenging the pigs, three Swiss Webster mice were orally inoculated with 25 oocysts by gavage to evaluate the viability of them. The inoculated mice were monitored for 60 , and after this period, they were euthanized for blood and brain collection. The blood samples were tested for the presence of antibodies anti-T. gondii by IFAT (Camargo, 1973), while the brain was used to detect tissue cysts by direct examination using smear slides and coverslips.

\section{Construction of plasmids, culture conditions, and purification of rROP2}

ROP2 recombinant protein (rROP2) was obtained, as described previously by Igarashi et al. (2008). Briefly, the DNA sequence of the gene encoding the rhoptry ROP2 antigen of $T$. gondii was obtained from the Genbank database (accession number: Z36906). The ROP2 antigen (nt. 1022-2125) has a predicted molecular mass of $54 \mathrm{kDa}$. The ROP2 open reading frame was amplified by a PCR assay using the primers ROP2 F (5'ATCGAATTCACGGATCCTGGAGAC3' introduced EcoRI recognition site, underline) and ROP2R (5'-TGAAAGCTTTCATGCCGGTTCTCC-3'; introduced HindIII recognition site, underlined). The resulting PCR product was $1103 \mathrm{bp}$. This fragment was digested overnight with EcoRI and HindIII endonucleases and ligated into pTrcHis B (Invitrogen, Life Technologies, USA) following the manufacturer's recommendations.

Each PCR product was purified with a QIAquick PCR purification Kit (Qiagen) designed to purify single or double-stranded PCR DNA fragments. A specific PCR product was obtained, and after digestion, with the respective restriction enzymes, it was precipitated with $0.1 \mathrm{~mL}$ of $100 \%$ ethanol and $0.01 \mathrm{~mL}$ of $3 \mathrm{M}$ sodium acetate and ligated into its respective vector using T4 DNA Ligase (Biolabs). Sequence analysis of the DNA fragment cloned in the plasmid was submitted to dideoxy sequencing methodology using the BigDye ${ }^{\circledR}$ Terminator v3.1 Cycle Sequencing Kit (Thermo Fisher Scientific, USA), at the ABI3730xI Genetic Analyzer (Thermo Fisher Scientific, USA). Transformed E. coli DH5-a bacteria were identified on LB/ampicillin agar plates, QIAprep Miniprep Kit (Qiagen), and colony-PCR with the same 
primers. Positive clones were confirmed by sequencing and transformed into E. coli Rosetta (DE3). The Rosetta strains (DE3) transformed with pTrcHis/ROP2 were grown with vigorous shaking at $37^{\circ} \mathrm{C}$ in $50 \mathrm{~mL}$ LB supplemented with $100 \mu \mathrm{g} / \mathrm{mL}$ ampicillin and $100 \mu \mathrm{g} / \mathrm{mL}$ chloramphenicol to an optical density at $600 \mathrm{~nm}$ of 0.8 . Protein production was then induced with isopropyl-D-thiogalactopyranoside (IPTG) at a final concentration of $1 \mathrm{mM}$. The culture was incubated with shaking at $37^{\circ} \mathrm{C}$ for $4 \mathrm{~h}$. The cells were harvested by centrifugation $(2,500 \times \mathrm{g}$ for $5 \mathrm{~min})$, and the pellets were resuspended and lysed in $20 \mathrm{mM}$ sodium phosphate and $500 \mathrm{mM}$ sodium chloride pH 7.8 followed by three freezing-thaw cycles to obtain the soluble phase. The soluble fraction was applied directly onto a Ni-NTA Superflow resin (Qiagen) pre-equilibrated with $20 \mathrm{mM}$ sodium phosphate and $500 \mathrm{mM}$ sodium chloride, $\mathrm{pH}$ 7.8. The recombinant soluble antigen was eluted from the resin by gravity flow with native elution buffer ( $200 \mathrm{mM}$ monobasic sodium phosphate and $5 \mathrm{M} \mathrm{NaCl} \mathrm{pH} \mathrm{4.0);} \mathrm{this} \mathrm{included} 30$ min of incubation with the elution buffer along with gentle agitation at $25^{\circ} \mathrm{C}$.

\section{Iscomatrix + rROP2 vaccine}

Iscomatrix was prepared as described by Kawasaki et al. (2007). This method involves the hydration of dried phospholipid/cholesterol films using an aqueous solution with a ratio of 2:1:2 Quil A/cholesterol/PC. Phosphatidylcholine $(8 \mathrm{mg}$ ) and cholesterol $(4 \mathrm{mg}$ ) were dissolved in $0.5 \mathrm{~mL}$ chloroform and evaporated at $45^{\circ} \mathrm{C}$. The lipid film was hydrated in $3 \mathrm{~mL}$ of Tris buffer $(\mathrm{pH} 7.4)$ containing $8 \mathrm{mg}$ of saponin Quil A at $25^{\circ} \mathrm{C}$ for $2 \mathrm{~h}$. The Iscomatrix/rROP2 vaccine was produced by the addition of the Iscomatrix adjuvant (1:1) to $200 \mu \mathrm{g}$ of $T$. gondii rROP2 in a final volume of $1 \mathrm{~mL}$.

\section{Animal experiments}

The maintenance and care of experimental animals complied with the Animal Ethics Committee of Londrina State University (CEUA 17/09). Twelve mixed breed pigs 25-30 days of age, including females and castrated males, were randomly allocated in cages (four animals each). The animals were left to acclimatize for 28 days before the experiment. They received food and water ad libitum. All pigs were serum negative (titer $<64)$ in the $T$. gondii IFA (Camargo, 1973). The pigs were divided into three groups, group 1 (G1) and group 2 (G2), and group 3 (G3) with 4 animals each. The G1 animals received Iscomatrix + rROP2 (200 $\mu \mathrm{g})$ four times nasally and three times intramuscularly. The $\mathrm{G} 2$ animals received only Iscomatrix, and the $\mathrm{G} 3$ animals received saline in the same manner as the G1. The intranasal (IN) instillations were performed on days $28,42,56$, and 72 , and intramuscular (IM) injections on days 86,93 , and 100 . The G1, G2, and G3 animals were challenged orally on day 110 with a high dose of VEG strain oocysts ( $4 \times 10^{4}$ sporulated oocysts). The pigs were treated on day three after challenge with sulfadiazine ( $3 \mathrm{mg} / \mathrm{kg}$ ) and trimethoprim (15 mg/kg) by the IM route (Garcia et al., 2005) to force encystation of parasites.

\section{Sampling and measurements}

Clinical signs and body temperature were recorded before and after the challenge. Serum samples were taken on days $-6,0,7,14,21,28,35,42,49,56,63,70,77,86,93,97,100,103,110,113,119,126,132$, and at cull (145) and stored at $-20^{\circ} \mathrm{C}$. Blood samples with EDTA were collected three days after challenge (d.a.c.) to detect parasitemia. At death, a pool of muscle (heart, tongue, diaphragm, and masseter) and brain samples were collected to investigate T. gondii cysts by mouse bioassay.

\section{rROP2 ELISA}

ELISA was performed as previously described (Garcia et al., 2005, 2006; Igarashi et al., 2008). Optimal dilutions of IgG, IgA, and IgM were established using checkerboard titrations with dilutions of sera, antigen, and conjugates. rRop2 was used as an antigen to coat the wells $(5 \mu \mathrm{g} / \mathrm{mL})$ of microtiter plates. 96 -well flat-bottomed polystyrene microtitration plates (Nunc-Immuno Plate, MaxiSorp, Denmark) were coated with $0.1 \mathrm{~mL}$ of antigen $(5 \mu \mathrm{g} / \mathrm{mL})$ diluted in $0.1 \mathrm{M}$ carbonate buffer $(\mathrm{pH} 9.6)$ and incubated overnight at $6{ }^{\circ} \mathrm{C}$. The plates were washed 3 times with TBS-tween 20 (50 mM tris, pH 7.4, containing $150 \mathrm{mM}$ sodium chloride and 0.05\% tween 20), and non-specific immune sites were blocked with a buffer containing $8 \%$ nonfat powdered milk. The control and test sera were diluted 1:200 for IgG, IgM, and IgA, in PBS-tween 20 plus 5\% nonfat dry milk and added to the microtitre plates in duplicate $\left(0.1 \mathrm{~mL}\right.$ in each well) and incubated for $1 \mathrm{~h}$ at $37^{\circ} \mathrm{C}$. After washing, anti-pig IgG, IgM, and IgA antibodies (Bethyl Laboratories Inc, Montgomery, TX, USA) were diluted 1:5000, 1:2500, and 1:5000, respectively, in 
PBS-tween 20 plus 5\% nonfat powdered milk, and $0.1 \mathrm{~mL}$ was added to each well and incubated for $1 \mathrm{~h}$ at $37^{\circ} \mathrm{C}$. After washing, the peroxidase activity was determined by adding $0.1 \mathrm{~mL}$ of ortho-phenylenediamine solution (40 mg ortho-phenylenediamine/100 mL of $0.1 \mathrm{M}$ phosphate citrate buffer, $\mathrm{pH} 6.0$ and $40 \mu \mathrm{L}$ of H2O2), and the reaction was blocked by adding $0.05 \mathrm{~mL}$ of $1 \mathrm{~N} \mathrm{HCl}$. The optical density (OD) was read at $490 \mathrm{~nm}$ in an ELISA microplate reader. Mean absorbance values were measured, and the OD value was calculated as previously described (Garcia et al., 2006). The samples were considered positive when DO> [(DO negative control; $n=15)+3$ standard deviations (negative control; $n=15$ )]. Positive and negative control sera were included on every plate.

\section{Mouse bioassay}

A $50 \mathrm{~g}$ brain sample and a pool of muscle samples with $12.5 \mathrm{~g}$ of tongue, masseter, diaphragm, and heart from each pig were used to check for the presence of $T$. gondii cysts as described previously (Dubey, 1998). Briefly, each sample was homogenized in a blender for 30 seconds in $250 \mathrm{~mL}$ of saline solution $(0.14 \mathrm{M} \mathrm{NaCl})$. After homogenization, $250 \mathrm{~mL}$ of pepsin solution $(50 \mathrm{~g})$ was added and incubated at $37^{\circ} \mathrm{C}$ for $1 \mathrm{~h}$. The homogenate was filtered through 2 layers gauze and centrifuged at $1180 \times \mathrm{g}$ for $10 \mathrm{~min}$. The supernatant was discarded, and the sediment was resuspended in $20 \mathrm{~mL}$ PBS ( $\mathrm{pH} 7.2), 15 \mathrm{~mL} 1.2 \%$ sodium bicarbonate ( $\mathrm{pH}$ 8.3) was added to the solution, and the solution was centrifuged at $1180 \times \mathrm{g}$ for $10 \mathrm{~min}$. The supernatant was discarded, and the sediment was resuspended in $5 \mathrm{~mL}$ of antibiotic saline solution (1,000 U penicillin and $100 \mu \mathrm{L}$ of streptomycin/mL of saline solution) and inoculated subcutaneously into three mice (1 $\mathrm{mL} / \mathrm{mouse})$.

\section{Examination of mice}

Animals that showed clinical signs of infection were euthanized, and impression smears of the lungs were fixed in methanol, stained with Giemsa, and examined microscopically. Blood samples were drawn from the mice that survived 60 days post-inoculation, and the brain of each mouse was examined microscopically for $T$. gondii cysts by squashing a portion of the brain between a coverslip and a glass slide. Serum from each mouse was diluted 1:16 and 1:64 and examined for T. gondii antibodies using IFA (Camargo, 1973). Mice were considered positive if animals had either tachyzoites, tissue cysts detected at samples microscopely, or IFA with titer $\geq 16$.

\section{Toxoplasma gondii parasitemia}

Toxoplasma gondii parasitemia followed the methodology describe by Costa et al. (1977) with some adjustments. Briefly, $5 \mathrm{~mL}$ of pig whole blood was collected and mixed with EDTA on day three after challenge and centrifuged at $2,000 \times$ g to separate the layers. The buffy coat was collected, and $0.5 \mathrm{~mL}$ was inoculated intraperitoneally into three mice for each sample. Mice were observed daily and euthanatized after 45 days to detect cysts and performing serology as described above.

\section{Real-time quantitative PCR on 529-bp repeat element}

Brain tissues from pigs were homogenized, and $25 \mathrm{mg}$ of each tissue was subjected to DNA extraction by using a commercial kit (PureLink Genomic DNA Mini Kit; Invitrogen, USA) according to the manufacturer's instructions. The DNA samples were stored at $-20^{\circ} \mathrm{C}$ until molecular analysis.

PCR amplification was performed in 96-wells plates using a StepOne ${ }^{\text {TM }}$ Plus (Life Technologies, EUA) as described by Reischl et al. (2003) to amplify a fragment of $162 \mathrm{bp}$ from $529 \mathrm{bp}$ repetitive fragment. Each $25 \mu \mathrm{l}$ reaction consisted 12,5 $\mathrm{\mu l}$ of TaqMan ${ }^{\circledR}$ Universal PCR MasterMix (Life Technologies, EUA), $0.7 \mu \mathrm{M}$ of each primer (Tox-9F and Tox-11R), $0.05 \mu \mathrm{M}$ of Tox-TP1, BSA (10 $\mu \mathrm{g} / \mathrm{ml}), 2 \mu \mathrm{L}$ of DNA template and ultrapure water. The reaction mixture was initially incubated at $95^{\circ} \mathrm{C}$ for $10 \mathrm{~min}$ followed by 45 amplification cycles that consisted of a denaturation step at $95^{\circ} \mathrm{C}$ for $1 \mathrm{~s}$, an annealing step at $58{ }^{\circ} \mathrm{C}$ for the $20 \mathrm{~s}$, and an extension step at $72{ }^{\circ} \mathrm{C}$ for $20 \mathrm{~s}$. Fluorescence at $530 \mathrm{~nm}$ (Tox-TP1) was measured at the end of each extension step. The negative control consisted of water samples without T. gondii and was included in each assay. The positive controls consisted of different concentrations of $T$. gondii DNA, $5 \mathrm{fg}, 50 \mathrm{fg}, 500 \mathrm{fg}, 5 \mathrm{pg}, 50 \mathrm{pg}$, and 500pg, which also were used for standard curve calculation. 


\section{Statistical analysis}

ANOVA and Kruskal-Wallis were used to show statistical differences in antibody serology responses, and Student's t-test was used to compare the averages. A comparison between mouse bioassay used the chi-square test. Protection against cyst formation in pigs was evaluated by estimating the preventable fraction (PF) as previously described (Siev, 1994) with some adjustments; PF $=p 2-p 1 / p 2$, where p2 $=\%$ of positive mice from the non-vaccinated pigs (G3) and $\mathrm{p} 1=\%$ of positive mice from vaccinated pigs (G1 or G2). P-value $<0.05$ was considered statistically significant.

\section{Results}

\section{Humoral immune and clinical signal responses}

The rROP2 protein used as antigen showed a band about $54 \mathrm{kDa}$ in SDS-PAGE only in the soluble fraction. All pigs in G1, G2, and G3 showed clinical signals beginning three d.a.c. The animals presented with mean rectal temperatures rising from $40.0^{\circ} \mathrm{C}$ to $41.0 \pm 0,569$ from 3 to 5 d.a.c., anorexia, and prostration at 5 d.a.c. when they were treated as described above. The animals from all groups recovered completely by day 8 post-challenge.

IgG, IgM, and IgA anti-T. gondii-rROP2 antibody results are shown in Figure 1. Cut-offs were determined for each antibody, IgGCO $=0.177 ;$ IgMCO $=0.237 ; \operatorname{lgACO}=0.305$. None of the antibody levels were above cut-off after nasal immunization. The IgG levels in G1 began to increase on day 93 and rose until 126 ( $p=0.00033$, t-test) before declining to the end of the experiment. The G2, and G3 groups had IgG levels just above the cut-off on day 126; however, the levels were lower than those seen in G1. The IgM and IgA responses in all groups were very similar to those of IgG. On the day of the challenge (day 110), all animals from G1 showed an average OD above the cut-off, IgG $(\mathrm{OD}=0.893 \pm 0.132 ; \mathrm{p}<0.0001$, t-test), $\operatorname{lgM}(\mathrm{OD}=0.778 \pm 0.544 ; \mathrm{p}<0.05)$ and $\operatorname{lgA}(\mathrm{OD}=0.895 \pm 0.368$; $p=0.0096$, t-test). After the challenge, all animals were serum converted.

\section{Cyst detection}

The mouse bioassay on blood and meat, and QPCR results are summarized in Table 1. Toxoplasma gondii parasitemia was not detected in G1 animals $(0 \%, 0 / 12)$, but was found in $\mathrm{G} 2(41.6 \%, 5 / 12)$ mice, and G3 animals $(16.6 \%, 2 / 12)$. Mouse muscle bioassay found $6 / 12(50 \%), 4 / 12$ (33.3\%), and 10/24 (58.3\%) positive mice in G1, G2, and $\mathrm{G} 3$, respectively. PF for the bioassay was $\mathrm{G} 1 \times \mathrm{G} 3=40 \%$, and $\mathrm{G} 2 \times \mathrm{G} 3=10.1 \%$.

Analysis of qPCR on brain tissue detected one positive animal in G1 (pig $2=6$ femtogram DNA equivalents (fg)), three in G2 (pig $5=1023 \mathrm{fg}$, $6=571 \mathrm{fg}$, and $7=364$ ), and finally two in G3 (pig $9=22 \mathrm{fg}$, and $12=6 \mathrm{fg}$ ).

\section{Discussion}

In the present study, we observed pigs immunized with rROP2 + Iscomatrix by IN did not show systemic antibody response; however, after IM inoculation, they raised all immunoglobulins, which we associated to partial protection against the high dose of $T$. gondii oocyst challenge. Although pigs from our study did not show a humoral response after intranasal immunization, previous studies have demonstrated pigs and cats produced IgG and IgM antibodies after vaccination with crude and recombinant ROP2 proteins of T. gondii (Cunha et al., 2012; Zulpo et al., 2012, 2017). Kringel et al. (2004) used tachyzoites from the RH strain plus CpG-oligodeoxynucleotides to infect pigs and observed 10 times more anti-T. gondii IgG from the immunized pigs. Freire et al. (2003) showed that an Iscom + T. gondii surface antigens (SAgs) vaccine for pigs was capable of stimulating a humoral immune response. Jongert et al. (2008) immunized pigs with a DNA vaccine expressing T. gondii GRA1 and GRA7, and they produced high levels of IgG antibodies. Additionally, crude rhoptries were used by Garcia et al. (2005) and Cunha et al. (2012) to immunize pigs, and they also observed partial protection against oocysts challenge, which was similar to the present study. Pork is one of the main transmission sources for humans, and considering that the major source of $T$. gondii infections in pregnant women was undercooked or raw meat (Cook et al., 2000), these results assume a high significance.

In the last decades, many countries have observed a decline in the prevalence of toxoplasmosis in pigs. In the US, it has decreased from 10.05\% to 2.7\% (Zimmerman et al., 1990; Hill et al., 2010), and in Brazil from 24\% to 7.2\% (Garcia et al., 1999; Silva et al., 2008). This decreasing prevalence is due to the introduction of modern management 

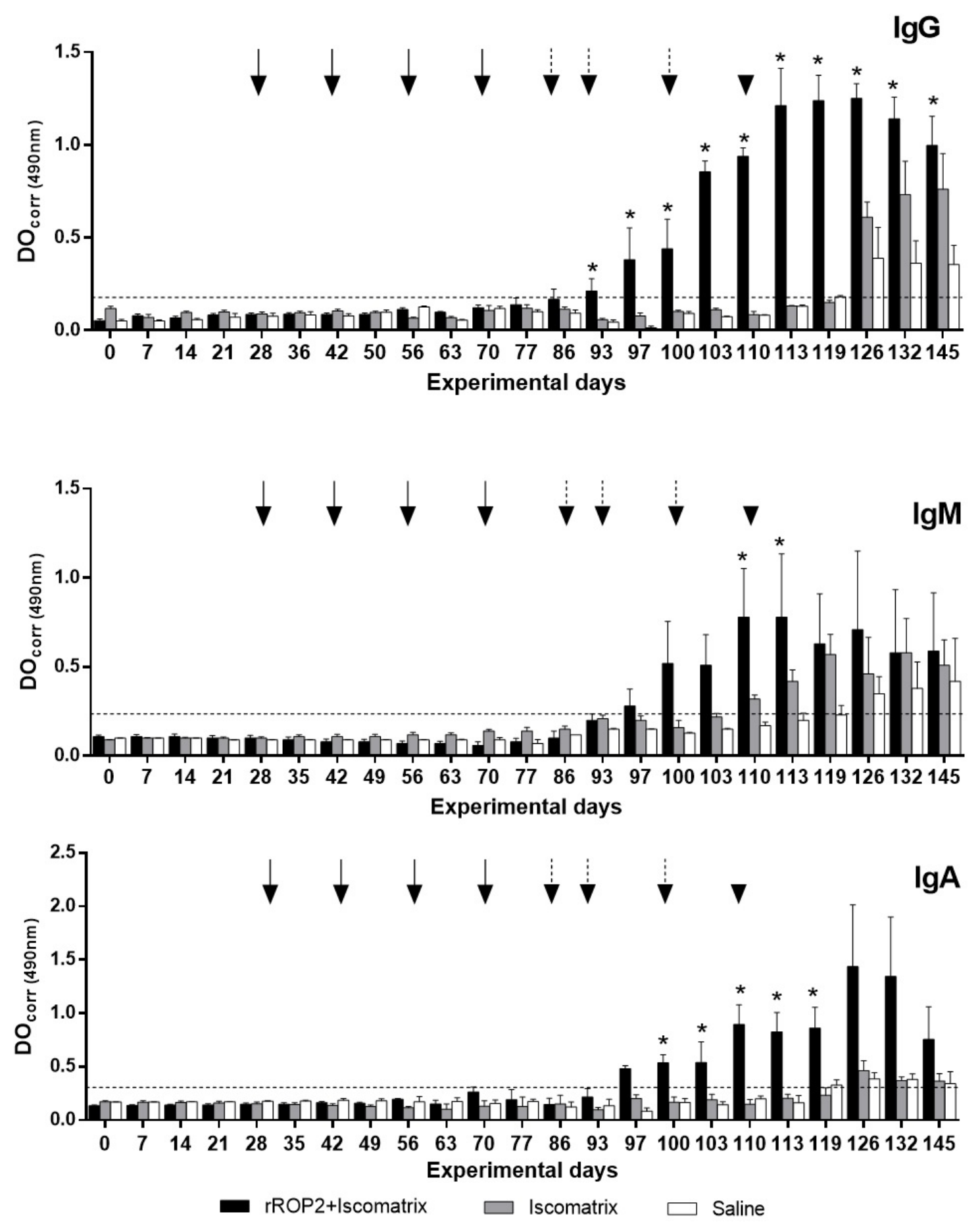

Figure 1. IgG, IgM, and IgA serological responses in pigs immunized with Toxoplasma gondii rROP2 by indirect ELISA. Black arrows, and dashed arrows, are days were nasal and intramuscular immunization were done, respectively. Arrowhead represents oocyst challenge. Data represent means \pm standard error of the mean $(S E M)$. * statistical difference $(p<0.05)($ ANOVA followed by t-test). DO = optical density.

systems. However, even this lower prevalence constitutes a considerable risk for human consumers. Hill et al. (2010) described that 820,000,000 individual $113 \mathrm{~g}$ servings of Toxoplasma infected pork could be available for consumption in the US each year, considering the prevalence of $2.7 \%$.

Additionally, consumers have a heightened interest in animal welfare, with an increasing market for organic meat. Furthermore, pork is labeled either as "free-range" or "outdoor bred and reared" in UK supermarkets. It means that since the environment is a potential source for toxoplasmosis, there is a possible increase in the risk of infection and, consequently, more cysts in pork. Therefore, based on the fact that cysts can remain in pork for 
Table 1. Detection of Toxoplasma gondii by mouse bioassay using blood and tissue form pigs immunized with recombinant T. gondii ROP2 proteins after challenge with VEG oocysts.

\begin{tabular}{|c|c|c|c|c|}
\hline \multirow{2}{*}{ Pig No. } & \multicolumn{3}{|c|}{ Mouse Bioassay } & \multirow{2}{*}{ qPCR* brain } \\
\hline & Blood & Pool of muscles & Total & \\
\hline \multicolumn{5}{|l|}{ G1 } \\
\hline 1 & $0 / 3$ & $2 / 3$ & $2 / 6$ & 0 \\
\hline 2 & $0 / 3$ & $3 / 3$ & $3 / 6$ & 6 \\
\hline 3 & $0 / 3$ & $0 / 3$ & $0 / 6$ & 0 \\
\hline 4 & $0 / 3$ & $1 / 3$ & $1 / 6$ & 0 \\
\hline Total & & \multicolumn{3}{|c|}{$6 / 24(25 \%)$} \\
\hline \multicolumn{5}{|l|}{ G2 } \\
\hline 5 & $2 / 3$ & $3 / 3$ & $5 / 6$ & 1023 \\
\hline 6 & $1 / 3$ & $0 / 3$ & $1 / 6$ & 571 \\
\hline 7 & $1 / 3$ & $1 / 3$ & $2 / 6$ & 364 \\
\hline 8 & $1 / 3$ & $0 / 3$ & $1 / 6$ & 0 \\
\hline Total & & \multicolumn{3}{|c|}{$9 / 24(37.5 \%)$} \\
\hline \multicolumn{5}{|l|}{ G3 } \\
\hline 9 & $0 / 3$ & $1 / 3$ & $1 / 6$ & 22 \\
\hline 10 & $0 / 3$ & $1 / 3$ & $1 / 6$ & 0 \\
\hline 11 & $0 / 3$ & $3 / 3$ & $3 / 6$ & 0 \\
\hline 12 & $2 / 3$ & $3 / 3$ & $5 / 6$ & 6 \\
\hline Total & & \multicolumn{3}{|c|}{$10 / 24$ (41.7\%) } \\
\hline
\end{tabular}

*femtogram DNA equivalents (fg).

more than two years (Dubey et al., 1998), and that pork is one of the most important sources of human $T$. gondii infections (Dubey et al., 1991), a vaccine against T. gondii in pigs would be very desirable, and should be focused on reducing tissue cysts.

Garcia et al. (2006) standardized an IgG-ELISA with crude rhoptries of $T$. gondii for pigs, and it was able to detect serum conversion in all animals on day 14 post-infection. Garcia et al. (2005), using an ELISA with T. gondii rhoptry antigens, detected seroconversion in pigs nine days after challenged with $4 \times 10^{4}$ oocyst of VEG strain. Here, we observed IgG antibody levels above the cut-off, in non-immunized pigs, nine days post-infection (day 119), and seroconversion in all animals on day 126, what could be related to the use of rROP2.

Mouse bioassay is considered the gold standard test for T. gondii cyst detection (Pinckney et al., 1994; Dubey et al., 1998). Here, mouse bioassay was used to detect tachyzoites from blood during the acute phase and bradyzoites from a pool of muscles after challenge to the pigs. Considering the results of all bioassays, we showed higher protection in vaccinated animals (G1) than in the adjuvant control (G2) and negative control animals (G3). As a highlight, one animal (n.3) from G1 did not have any parasite detected in either blood, muscles, or brain. Similarly, in two previous studies, we observed better protection in vaccinated animals using crude rhoptries delivered subcutaneously and nasally (Garcia et al., 2005; Cunha et al., 2012). Additionally, Dubey et al. (1991) observed fewer positive mice in bioassays on pigs immunized with a live RH strain than in the negative controls. Garcia et al. (2017) used the same qPCR and methodology and was able to detect $50 \mathrm{fg}$ of DNA equivalent; however, using retina tissues. Here, less than $20 \mathrm{fg}$ was detected, which could show that the brain area a better tissue to detect parasite DNA.

Clinical signs of $T$. gondii in pigs depend on breed, age, nutrition, strain characteristic, method of inoculation, and several infecting parasites (Dubey, 1994; Dubey et al., 1994). The animals from our experiment infected with a high dose of oocysts showed similar signs as the study by Garcia et al. (2005), who also used a high dose of oocysts. This high dose was used and combined with treatment to ensure the formation of a high number of tissue cysts. 


\section{Conclusion}

The IN immunization of Iscomatrix/rROP2 was not able to stimulate a systemic humoral immune response; however, when IM injection was used, these animals presented higher antibody titers than the other groups. Additionally, the immunized animals did not have any detectable parasites in their blood three days after infection, and they had fewer cysts and parasites in the brain than the controls. In conclusion, partial protection was observed.

\section{References}

Burrells A, Benavides J, Cantón G, Garcia JL, Bartley PM, Nath M, et al. Vaccination of pigs with the S48 strain of Toxoplasma gondii-safer meat for human consumption. Vet Res 2015; 46(1): 47. http://dx.doi.org/10.1186/s13567-015-0177-0. PMid:25928856.

Camargo ME. Introdução às técnicas de imunofluorescência. Rev Bras Patol Clin 1973; 10: 143-171.

Cook AJC, Gilbert RE, Buffolano W, Zufferey J, Petersen E, Jenum PA, et al. Sources of Toxoplasma infection in pregnant women: European multicentre case-control study. BMJ 2000; 321(7254): 142-147. http://dx.doi.org/10.1136/bmj.321.7254.142. PMid:10894691.

Copland MJ, Rades T, Davies MN. Hydration of lipid films with an aqueous solution of Quil A: a simple method for the preparation of immune-stimulating complexes. Int J Pharm 2000; 196(2): 135-139. http://dx.doi.org/10.1016/S0378-5173(99)00407-X. PMid:10699704.

Costa AJ, Araujo FG, Costa JO, Lima JD, Nascimento E. Experimental infection of bovines with oocysts of Toxoplasma gondii. J Parasitol 1977; 63(2): 212-218. http://dx.doi.org/10.2307/3280042. PMid:558305.

Cox JC, Coulter AR. Adjuvants: a classification and review of their modes of action. Vaccine 1997; 15(3): 248-256. http://dx.doi. org/10.1016/S0264-410X(96)00183-1. PMid:9139482.

Cunha IA, Zulpo DL, Bogado AL, Barros LD, Taroda A, Igarashi M, et al. Humoral and cellular immune responses in pigs immunized intranasally with crude rhoptry proteins of Toxoplasma gondii plus Quil-A. Vet Parasitol 2012; 186(3-4): 216-221. http://dx.doi. org/10.1016/j.vetpar.2011.11.034. PMid:22137347.

Dubey JP, Baker DG, Davis SW, Urban JF Jr, Shen SK. Persistence of immunity to toxoplasmosis in pigs vaccinated with a nonpersistent strain of Toxoplasma gondii. Am J Vet Res 1994; 55(7): 982-987. PMid:7978639.

Dubey JP, Lunney JK, Shen SK, Kwok OC. Immunity to toxoplasmosis in pigs fed irradiated Toxoplasma gondii oocysts. J Parasitol 1998; 84(4): 749-752. http://dx.doi.org/10.2307/3284582. PMid:9714205.

Dubey JP, Urban JFJr, Davis SW. Protective immunity to toxoplasmosis in pigs vaccinated with a nonpersistent strain of Toxoplasma gondii. Am J Vet Res 1991; 52(8): 1316-1319. PMid:1928915.

Dubey JP. Refinement of pepsin digestion method for isolation of Toxoplasma gondii from infected tissues. Vet Parasitol 1998; 74(1): 75-77. http://dx.doi.org/10.1016/S0304-4017(97)00135-0. PMid:9493311.

Dubey JP. Toxoplasmosis of animals and humans. 2nd ed. Boca Raton: CRC Press; 2010.

Dubey JP. Toxoplasmosis. J Am Vet Med Assoc 1994; 205(11): 1593-1598. PMid:7730132.

El Hajj H, Demey E, Poncet J, Lebrun M, Wu B, Galéotti N, et al. The ROP2 family of Toxoplasma gondii rhoptry proteins: proteomic and genomic characterization and molecular modeling. Proteomics 2006; 6(21): 5773-5784. http://dx.doi.org/10.1002/ pmic.200600187. PMid:17022100.

Freire RL, Navarro IT, Bracarense APFRL, Gennari SM. Vaccination of pigs with Toxoplasma gondii antigens incorporated in immunostimulating complexes (iscoms). Arq Bras Med Vet Zootec 2003; 55(4): 388-396. http://dx.doi.org/10.1590/S010209352003000400002.

Garcia J, Gennari SM, Navarro IT, Machado RZ, Sinhorini IL, Freire RL, et al. Partial protection against tissue cysts formation in pigs vaccinated with crude rhoptry proteins of Toxoplasma gondii. Vet Parasitol 2005; 129(3-4): 209-217. http://dx.doi.org/10.1016/j. vetpar.2005.01.006. PMid:15845275.

Garcia JL, Burrells A, Bartley PM, Bartley K, Innes EA, Katzer F. The use of ELISA, nPCR and qPCR for diagnosis of ocular toxoplasmosis in experimentally infected pigs. Res Vet Sci 2017; 115: 490-495. http://dx.doi.org/10.1016/j.rvsc.2017.07.022. PMid:28787692.

Garcia JL, Navarro IT, Ogawa L, Oliveira RC, Kobilka E. Soroprevalência epidemiologia e avaliação ocular da toxoplasmose humana na zona rural de Jaguapitã (Paraná), Brasil. Rev Panam Salud Publica 1999; 6(3): 157-163. http://dx.doi.org/10.1590/ S1020-49891999000800002. PMid:10517092.

Garcia JL, Navarro IT, Vidotto O, Gennari SM, Machado RZ, da Luz Pereira AB, et al. Toxoplasma gondii: comparison of a rhoptryELISA with IFAT and MAT for antibody detection in sera of experimentally infected pigs. Exp Parasitol 2006; 113(2): 100-105. http://dx.doi.org/10.1016/j.exppara.2005.12.011. PMid:16458299. 
Hill DE, Haley C, Wagner B, Gamble HR, Dubey JP. Seroprevalence of and risk factors for Toxoplasma gondii in the US swine herd using sera collected during the National Animal Health Monitoring Survey (Swine 2006). Zoonoses Public Health 2010; 57(1): 5359. http://dx.doi.org/10.1111/j.1863-2378.2009.01275.x. PMid:19744304.

Igarashi M, Kano F, Tamekuni K, Machado RZ, Navarro IT, Vidotto O, et al. Toxoplasma gondii: evaluation of an intranasal vaccine using recombinant proteins against brain cysts formation in BALB/c mice. Exp Parasitol 2008; 118(3): 386-392. http://dx.doi. org/10.1016/j.exppara.2007.10.002. PMid:18154953.

Igarashi M, Zulpo DL, Cunha IAL, Barros LD, Pereira VF, Taroda A, et al. Toxoplasma gondii: humoral and cellular imune response of BALB/c mice immunized via intranasal route with rTgROP2. Rev Bras Parasito/ Vet 2010; 19(4): 210-216. http://dx.doi.org/10.1590/ S1984-29612010000400004. PMid:21184696.

Jongert E, Melkebeek V, De Craeye S, Dewit J, Verhelst D, Cox E. An enhanced GRA1-GRA7 cocktail DNA vaccine primes antiToxoplasma immune responses in pigs. Vaccine 2008; 26(8): 1025-1031. http://dx.doi.org/10.1016/j.vaccine.2007.11.058. PMid:18221825.

Kawasaki PM, Kano FS, Tamekuni K, Garcia JL, Marana ER, Vidotto O, et al. Immune response of BALB/c mouse immunized with recombinant MSPs proteins of Anaplasma marginale binding to immunostimulant complex (ISCOM). Res Vet Sci 2007; 83(3): 347354. http://dx.doi.org/10.1016/j.rvsc.2007.02.002. PMid:17395222.

Kringel H, DubeyJP, Beshah E, Hecker R, Urban JFJr. CpG-oligodeoxynucleotides enhance porcine immunity to Toxoplasma gondii. Vet Parasito/ 2004; 123(1-2): 55-66. http://dx.doi.org/10.1016/j.vetpar.2004.01.021. PMid:15265571.

Lövgren K, Morein B. The requirement of lipids for the formation of immunostimulating complexes (iscoms). Biotechnol Appl Biochem 1988; 10(2): 161-172. http://dx.doi.org/10.1111/j.1470-8744.1988.tb00012.x. PMid:2838046.

Mishima M, Xuan X, Yokoyama N, Igarashi I, Fujisaki K, Nagasawa H, et al. Recombinant feline herpesvirus type 1 expressing Toxoplasma gondii ROP2 antigen inducible protective immunity in cats. Parasitol Res 2002; 88(2): 144-149. http://dx.doi.org/10.1007/ s004360100429. PMid:11936503.

Nakaar V, Ngô HM, Aaronson EP, Coppens I, Stedman TT, Joiner KA. Pleiotropic effect due to targeted depletion of secretory rhoptry protein ROP2 in Toxoplasma gondii.J Cell Sci 2003; 116(11): 2311-2320. http://dx.doi.org/10.1242/jcs.00382. PMid:12711703.

Pinckney RD, Lindsay DS, Blagburn BL, Boosinger TR, McLaughlin SA, Dubey JP. Evaluation of the safety and efficacy of vaccination of nursing pigs with living tachyzoites of two strains of Toxoplasma gondii. J Parasitol 1994; 80(3): 438-448. http://dx.doi. org/10.2307/3283415. PMid:8195946.

Reischl U, Bretagne S, Krüger D, Ernault P, Costa J. Comparison of two DNA targets for the diagnosis of toxoplasmosis by real-time PCR using fluorescence resonance energy transfer hybridization probes. BMC Infect Dis 2003; 3(1): 7. http://dx.doi. org/10.1186/1471-2334-3-7. PMid:12729464.

Saavedra R, Becerril MA, Dubeaux C, Lippens R, De Vos MJ, Hérion P, et al. Epitopes recognized by human T lymphocytes in the ROP2 protein antigen of Toxoplasma gondii. Infect Immun 1996; 64(9): 3858-3862. http://dx.doi.org/10.1128/IAl.64.9.38583862.1996. PMid:8751939.

Siev D. Estimating vaccine efficacy in prospective studies. Prev Vet Med 1994; 20(4): 279-296. http://dx.doi.org/10.1016/01675877(94)90061-2.

Silva AV, Boareto H, Isbrecht FB, da Silva RC, Langoni H. Ocorrência de anticorpos anti-Toxoplasma gondii em suínos da região oeste do Paraná, Brasil. Vet Zootec 2008; 15(2): 263-266.

Zimmerman JJ, Dreesen DW, Owen WJ, Beran GW. Prevalence of toxoplasmosis in swine from lowa. J Am Vet Med Assoc 1990; 196(2): 266-270. PMid:2298652.

Zulpo DL, Headley SA, Biazzono L, Cunha IAL, Igarashi M, Barros LD, et al. Oocyst shedding in cats vaccinated by the nasal and rectal routes with crude rhoptry proteins of Toxoplasma gondii. Exp Parasito/ 2012; 131(2): 223-230. http://dx.doi.org/10.1016/j. exppara.2012.04.006. PMid:22542988.

Zulpo DL, Igarashi M, Sammi AS, Santos JR, Sasse JP, Cunha IAL, et al. rROP2 from Toxoplasma gondii as a potential vaccine against oocyst shedding in domestic cats. Rev Bras Parasito/ Vet 2017; 26(1): 67-73. http://dx.doi.org/10.1590/s1984-29612017007. PMid:28403374.

Zulpo DL, Sammi AS, Santos JR, Sasse JP, Martins TA, Minutti AF, et al. Toxoplasma gondii: a study of oocyst re-shedding in domestic cats. Vet Parasito/ 2018; 249: 17-20. http://dx.doi.org/10.1016/j.vetpar.2017.10.021. PMid:29279081. 